\title{
A metformin-monoterápia és a szitagliptin/metformin fix kombináció egyéves perzisztenciája
}

\author{
Simonyi Gábor dr. ${ }^{1}$ - Ferenci Tamás dr. ${ }^{2}$ \\ ${ }^{1}$ Szent Imre Egyetemi Oktatókórház, Anyagcsere Központ, Budapest \\ ${ }^{2}$ Óbudai Egyetem, Neumann János Informatikai Kar, Élettani Szabályozások Csoport, Budapest
}

\begin{abstract}
Bevezetés: A 2-es típusú cukorbetegség kezelésében fontos a glykaemiás célok elérése. Ennek fontos tényezője a diéta mellett a gyógyszeres kezelés terápiahúsége. Célkitüzés: A metformin-monoterápia és a szitagliptin/metformin fix kombináció egyéves perzisztenciájának összehasonlítása 2-es típusú cukorbetegekben. Módszer: Az Országos Egészségbiztosítási Pénztár vényforgalmi adataira alapozva 2012. október 1. és 2013. szeptember 30. között első alkalommal metformin, illetve szitagliptin/metformin fix kombináció receptjeit kiváltó betegeket választottak ki. E betegek a bevonás előtti egy év során hasonló készítményeket nem szedtek. A túlélésanalízis klasszikus eszköztárát alkalmazták a perzisztencia modellezésére. A „túlélési idő” a gyógyszer szedésének kezdetétől annak abbahagyásáig eltelt idő volt. Mint diszkrét túléléselemzési modell, komplementer log-log link függvényt használó általánosított lineáris modellt alkalmaztak a vizsgálatban. Eredmények: A vizsgált időszakban 63386 beteg kezdett metformin-monoterápiát, illetve 10039 beteg kapott szitagliptin/metformin fix kombinációt. A betegek követése során a metformin-monoterápia egyéves perzisztenciája $30 \%$, míg a szitagliptin/metformin kombinációt szedőkben ez $58 \%$-nak bizonyult. A metforminszedés átlagos perzisztenciájának időtartama 173,4 nap volt, a szitagliptin/metformin fix kombinációt szedóké 261,9 nap. A metformin-monoterápia elhagyásának kockázata a szitagliptin/metformin fix kombinációhoz képest több mint kétszeres volt $(\mathrm{HR}=2,267, \mathrm{p}<0,001)$. Következtetések: A szerző́k igazolták, hogy a metformin-monoterápia, illetve a szitagliptin/metformin fix kombináció között szignifikáns különbség van az egyéves perzisztencia vonatkozásában. Az eredmények azt igazolták, hogy a betegek terápiahúsége szempontjából előnyösebb a szitagliptin/metformin fix kombináció. Orv. Hetil., 2016, 157(16), 618-622.
\end{abstract}

Kulcsszavak: perzisztencia, metformin, szitagliptin/metformin fix kombináció, 2-es típusú cukorbetegség

\section{One year persistence of metformin monotherapy versus metformin/sitagliptin fixed dose combination}

Introduction: In treatment of type 2 diabetes mellitus it is important to reach glycaemic targets. The elements of this are the adequate diet and the patient's adherence to medication. Aim: The aim of the authors was to investigate the one year persistence of the metformin monotherapy and sitagliptin/metformin fixed dose combination in type 2 diabetic patients. Method: National Health Insurance Found prescriptions database of Hungary on pharmacy-claims between October 1, 2012 and September 30, 2013 was analyzed. The authors identified patients who filled prescriptions for metformin monotherapy and fixed dose combinations of sitagliptin/metformin prescribed for the first time. Patients have not received similar drugs one year previous to study. To model the persistence, the apparatus of survival analysis was used, where "survival" was the time to abandon the medication. As it was available to month precision, discrete time survival analysis was applied: a generalized linear model was estimated with complementary log$\log$ link function with the kind of drug being the only explanatory variable. Results: During the trial period, metformin monotherapy or sitagliptin/metformin fixed dose combination was started in 63,386 and 10,039 patients, respectively. One year persistence rate in patients with metformin monotherapy was $30 \%$, and $58 \%$ in patients with sitagliptin/metformin fixed dose combination. Considering only the 360 -day study period, the mean duration of persistence was 173.4 days in patients on metformin monotherapy and 261.9 days on sitagliptin/metformin fixed dose combination. The hazard of discontinuation was more than twofold higher during treatment with metformin monotherapy compared with the use of the sitagliptin/metformin fixed dose combination (hazard ratio $=2.267$, 
$\mathrm{p}<0.001)$. Conclusions: There is a significant difference between the one year persistence of metformin monotherapy and sitagliptin/metformin fixed dose combination in type 2 diabetic patients. The result demonstrated sitagliptin/ metformin fixed dose combination has a favourable patients' adherence as compared to metformin monotherapy.

Keywords: persistence, metformin, sitagliptin/metformin fixed dose combination, type 2 diabetes mellitus

Simonyi, G., Ferenci, T. [One year persistence of metformin monotherapy versus metformin/sitagliptin fixed dose combination]. Orv. Hetil., 2016, 157(16), 618-622.

(Beérkezett: 2016. február 2.; elfogadva: 2016. február 25.)

\begin{abstract}
Rövidítések
BNO = Betegségek Nemzetközi Osztályozása; CI = konfidenciaintervallum; DPP-4 = dipeptidil-peptidáz-4; GIP = (glucose-dependent insulinotropic peptide) glükózdependens inzulinotrop peptid; GLP-1 = (glucagon-like peptide-1) glükagonszerú peptid-1; HR = (hazard ratio) kockázati arány; IDF $=($ International Diabetes Federation $)$ Nemzetközi Diabetes Szövetség; MDT = Magyar Diabetes Társaság; OEP = Országos Egészségbiztosítási Pénztár; $\mathrm{SE}=$ (standard error) standard hiba
\end{abstract}

A 2-es típusú diabetes mellitusban szenvedők száma világszerte a 2014-es 387 millióról 2040-re 642 millióra nőhet az IDF idén kiadott, legfrissebb előrejelzése szerint [1]. Jermendy és mtsai 2005-2006-ban a 20-69 év közötti populációban egy reprezentatív szűrővizsgálatot végeztek, amelynek során a diabetes hazai súlyozott gyakoriságát - a 20-69 éves teljes populációra vetítve 7,47\%-nak találták [2]. Ez az adat lényegében megegyezik az IDF Diabetes Atlasz 7. kiadásában olvasható adatokkal, ahol a hazai diabetesincidenciát 7-8\% közöttinek becsülték [1].

A 2-es típusú diabetes mellitus progrediáló, krónikus betegség, ezért kezelése és gondozása élethosszig tart. A 2-es típusú cukorbetegséghez rendszerint több, szintén cardiovascularis kockázati tényező járulhat (például dyslipidaemia, elhízás, hypertonia), amelyek szintén folyamatos kezelést és ellenőrzést igényelnek. A 2-es típusú cukorbetegség komplex kezelése során az életmód-terápia (testmozgás és diéta) mellett legtöbb esetben az antidiabetikus gyógyszerek alkalmazása is szükséges. Mindezek mellett a megfelelő glykaemiás helyzet elérése során fontos tényező a vércukorszint megfelelő időközönként végzett önellenőrzése, továbbá a $\mathrm{HbA}_{\mathrm{lc}}$-értékek meghatározása [3]. A megfelelően edukált és motivált cukorbeteg jó adherenciája esetén a szénhidrát-anyagcsere kézben tartható, amelyet a $\mathrm{HbA}_{\mathrm{lc}}$-célok elérése és tartása is visszatükröz [4]. Mindezek jelentősége hosszú távon a macro- és a microvascularis szövődmények elkerülésében vagy késleltetésében csúcsosodik ki.

A hazai és a nemzetközi irányelvek szerint a 2-es típusú cukorbetegség kezelésében az életmód-terápiát követően - ellenjavallat hiányában - metforminterápia java- solt. Ennek elégtelensége esetén számos kombinációt adhatunk, amelyek egyike a metformin + DDP-4-gátló együttes alkalmazása [5].

Vizsgálatunkban azt a célt tűztük ki magunk elé, hogy összehasonlítsuk a metformin, illetve a szitagliptin/metformin fix kombináció egyéves perzisztenciáját.

\section{Betegek és módszer}

Az Országos Egészségbiztosítási Pénztár (OEP) adatbázisának adatait használtuk retrospektív vizsgálatunkban. Az adatbázisból olyan betegeket választottunk ki, akik 2012. október 1. és 2013. szeptember 30-a között váltottak ki metformint vagy szitagliptin/metformin fix kombinációt, mint hatóanyagokat tartalmazó recepteket. E betegek a megelőző egy évben hasonló készítmények receptjeit nem váltották ki, ezért ebból a szempontból új gyógyszerszedőknek tekintettük őket. A betegek receptkiváltásait 14 hónapig követtük. A követési időszak alatt elhalálozott betegeket kivettük elemzésünkből. Hatvannapos gyógyszerkihagyást toleráltunk (grace periódus). Az egyéves követés során azt vizsgáltuk, hogy a betegek mekkora hányada folytatta a metformin, illetve a szitagliptin/metformin terápiát. A gyógyszerkiváltási adatok 30 napos időközönként voltak elérhetőek, és ennek alapján határoztuk meg a perzisztens betegek számát.

A metformin-monoterápia és a szitagliptin/metformin fix kombináció perzisztenciamodellezésére a túlélésanalízis klasszikus eszköztárát alkalmaztuk, ahol a „túlélési ido"” a gyógyszer szedésének kezdetétől annak abbahagyásáig eltelt idő volt. Az egyetlen magyarázó változó a gyógyszer-kombináció típusa volt. A perzisztenciaadatok 30 napos frekvenciával voltak elérhetők, ezért diszkrét idejű túlélést becsültünk meg, majd ábrázoltuk az idő függvényében. A modellezéshez komplementer log-log link függvényt használó általánosított lineáris modellt becsültünk, amely a jól ismert (folytonos idejü) túléléselemzés bevált diszkrét idejü megfelelője [6]. A gyógyszerek között a hazárd proporcionalitását úgy ellenőriztük, hogy hozzáadtuk a modellhez a gyógyszer és az eltelt idő interakcióját, és összehasonlítottuk ennek a - szaturált - modellnek az illeszkedését az eredeti modellével [7]. Amennyiben a nem proporcionalitás 
nem volt jelentős, úgy meghatároztuk a gyógyszerszedés abbahagyásának hazárdját is, a metformin/szitagliptin fix kombinációhoz hasonlítva (HR: hazárd arány). Kiszámoltuk mindkét készítmény szedésének a 12 hónapra korlátozott átlagos túlélési idejét [8] is.

\section{Eredmények}

2012. október 1. és 2013. szeptember 30. között 63386 betegnek indítottak metformin-, míg 10039 betegnek szitagliptin/metformin fix kombinációs terápiát.

A metforminterápiát az első hónap után a betegek 34\%-a, míg a harmadik hónapra a betegek majdnem fele (48\%) hagyta el. Fél év elteltével a nonadherens betegek aránya $60 \%$ volt, azaz a betegek mindössze $40 \%$-a maradt metforminkezelésen. A metforminterápia egyéves perzisztenciája 30\% volt.

A szitagliptin/metformin fix kombináció esetében az első hónapra a terápiaelhagyók aránya $16 \%$ volt, a harmadik hónapra ez 23\%-ra nőtt. Fél év elteltével még a betegek 69\%-a szedte az elöírt készítményt. A metforminhoz képest a perzisztenciaelőny ekkor 29 százalékpont volt. A szitagliptin/metformin fix kombináció egyéves perzisztenciája 58\%-nak bizonyult, amely azt jelentette, hogy a féléves adatokhoz hasonlóan a szitagliptin/metformin fix kombináció lényegében megtartotta perzisztenciaelőnyét a metforminterápiához képest (1.ábra).

A 360 napra korlátozott intervallumból számolt átlagos perzisztenciaidő 173,4 (SE: 0,567 ) nap volt a met- formin, míg 261,9 (SE: 1,344) nap a szitagliptin/metformin fix kombináció esetén.

A diszkrét túléléselemzési modell eredményei szerint a nem proporcionalitás ezrelék alatti volt, ezért alkalmazhattuk a proporcionális modellt és ennek révén a HR-t. A metforminterápia elhagyásának a hazárdja a szitagliptin/metformin fix kombinációhoz képes több mint kétszeresnek bizonyult $(\mathrm{HR}=2,267$ [95\% CI: 2,198$2,342], \mathrm{p}<0,001)$.

\section{Megbeszélés}

Nemzetközi viszonylatban is egyedülálló vizsgálatunkban igazoltuk, hogy a metformin/szitagliptin fix kombináció egyéves perzisztenciája több mint kétszeres a metformin-monoterápiához képest. Egy korábbi hazai vizsgálatban 2007. január 1. és 2009. március 31. közötti időszak OEP receptkiváltási adatait felhasználva tanulmányozták néhány orális antidiabetikus terápia adherenciáját. A metformin-monoterápia egyéves perzisztenciáját 47,7\%-nak találták, míg a szulfanilureaterápia egyéves perzisztenciája 45,4\%-os volt [9]. Ebben a vizsgálatban megengedőbb grace periódust (180 nap) alkalmaztak, szemben a vizsgálatunkban használt - szigorúbb - 60 nappal. Ez áll annak a hátterében, hogy a korábbi vizsgálattal szemben, ahol 47,7\%-os volt a metforminterápiaperzisztencia, a mi vizsgálatunkban ez 30\%-nak, azaz lényegesen alacsonyabbnak bizonyult. A korábbi vizsgálat 180 napos grace periódusát 60 nappal számolva valószí-

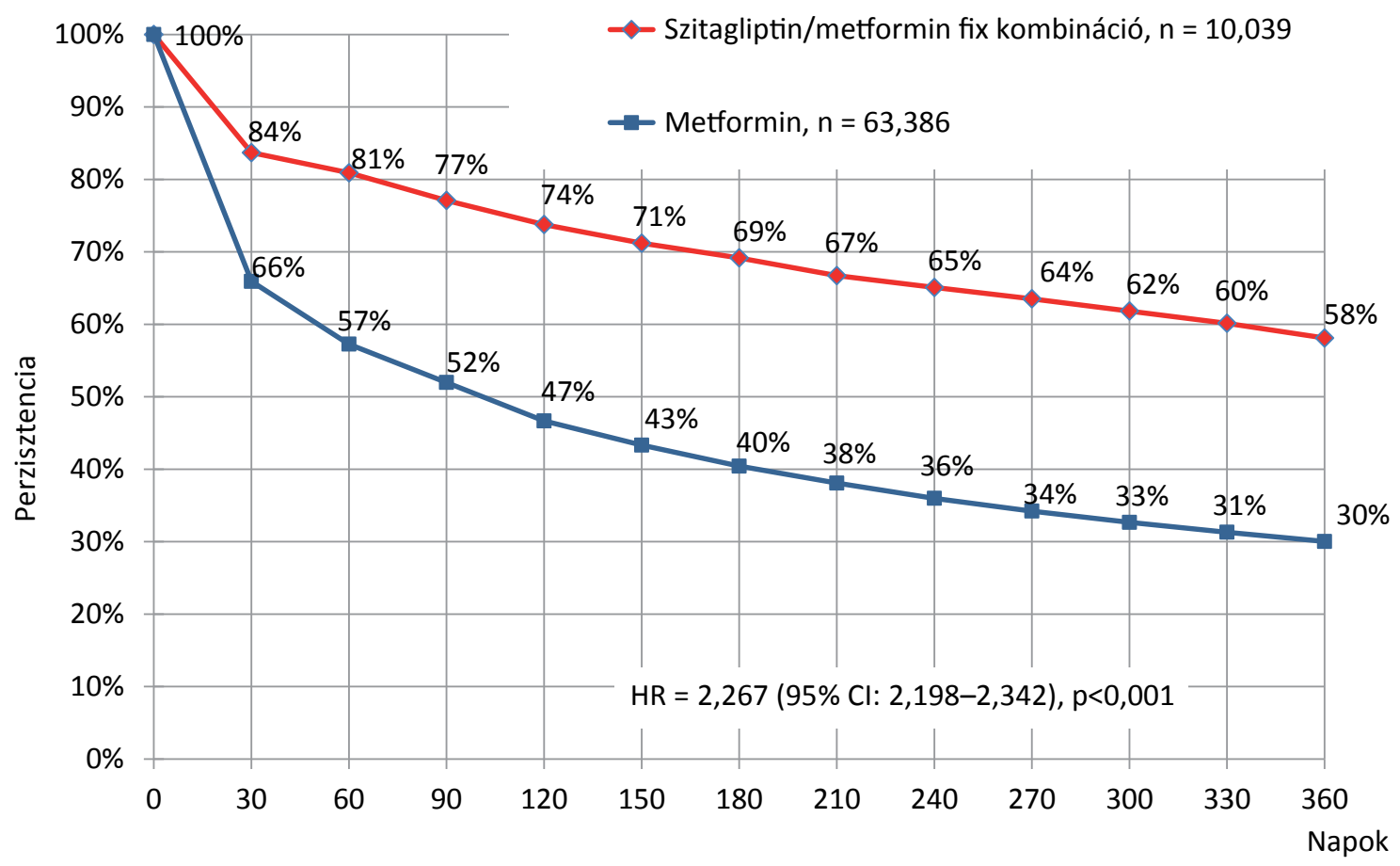

1. ábra | A metformin és a szitagliptin/metformin fix kombináció egyéves terápiahúsége 
núleg a miénkhez hasonló egyéves perzisztenciát eredményezett volna.

A metformin alacsony egyéves perzisztenciája nem igazán kedvező eredmény, mivel 2-es típusú cukorbetegségben az antidiabetikus terápia egyik alappillére éppen a metformin. Az első hónap 34\%-os lemorzsolódásában a metforminintolerancia is szerepet játszhat. Ennek legfontosabb oka a gastrointestinalis mellékhatások jelentkezése. Általában a metforminszedés megkezdésekor a betegek 25\%-ában jelentkezhet hányinger, hányás, míg mintegy felében hasmenés. E mellékhatások általában azért jelentkeznek ilyen nagy arányban, mivel gyakran elmarad a metformin fokozatos feltitrálása a maximálisan tolerálható dózisig. Ugyanakkor talán kevéssé ismert, hogy a metforminszedés elején jelentkező mellékhatások többsége később megszűnik, ezért igen alacsony arányú lehet a valódi metforminintolerancia [10].

A 2 -es típusú cukorbetegek kezelésekor - amennyiben metformin-monoterápiával nem érhetô el a glykaemiás cél - a metformin számos más antidiabetikummal kombinálható. Ezek egyike a DPP-4-gátló szitagliptin. Ennek tükrében a mindennapos gyakorlat számára is fontos üzenetet hordoznak eredményeink, miszerint a szitagliptin/metformin fix kombinációval szignifikánsan (több mint kétszeresen) javítható a cukorbetegek terápiahúsége. Ennek jelentőségét nehéz lenne lebecsülni, mivel a glykaemiás célok elérésének egyik alapvető tényezője a jó terápiahúség. Ez hosszú távon pedig a micro- és macrovascularis szövődmények kialakulásának kockázatcsökkentésében bír kiemelkedő szereppel.

\section{A metformin és a szitagliptin szinergista hatásai}

A biguanidcsoportba tartozó metformin csökkenti a basalis és a postprandialis vércukor szintjét. Egyrészt mérsékeli a májban történő glükóztermelést (a glükoneogenezis és a glükogenolízis gátlása útján), illetve növeli az inzulinérzékenységet, mivel javítja az izomzatban a perifériás glükózfelvételt, továbbá késlelteti a bélból a glükózfelszívódást [11]. A metformin kevésbé ismert hatása még, hogy emeli a GLP-1-szintet [12], amelyet a GLP-1-lebontást gátló hatásának tulajdonítanak.

Az inkretinek a bélfal sejtjeiben termelődő hormonok, amelyek serkentik a pancreas endokrin múködését. A bélben termelt inkretinek két legfontosabb képviselője a GIP (glükózdependens inzulinotrop peptid) és a GLPl (glükagonszerú peptid-1). Klinikai szempontból a GLP-1-et tartjuk a legfontosabb inkretin hormonnak.

A vékonybél L-sejtjei termelik a GLP-1-et, K-sejtjei pedig a GIP-et. Ezek glükózfüggő módon serkentik a béta-sejt inzulinszekrécióját, és elősegítik a béta-sejtek proliferációját is. A GLP-1 ezenkívül csökkenti az alfasejtek glükagonszekrécióját és a táplálékfelvételt, továbbá lassítja a gyomor ürülését. A keringésbe jutott GLPl-et szinte azonnal elbontja a DPP-4 enzim. A DPP-4 enzim szelektív gátlásával a természetes inkretin hatást növelhetjük meg. A DPP-4-gátlók mindegyike inaktívvá teszi a DPP-4 enzimet és ezáltal tartósan, az élettanihoz közeli inkretinszintet biztosít 2-es típusú cukorbetegségben. A DPP-4-gátlással az aktív GLP-1 mennyisége mintegy négyszeresre, a fél életideje $1-2$ percről több órára nó. A GLP-1-analógok, illetve -agonisták pedig a természetes GLP-1-hez képest jobban ellenállnak a DPP-4 enzimnek, így segítve elő a GLP-1 hatását [13].

$\mathrm{Az}$ inkretin tengelyre ható DPP-4-gátlók számos előnyös tulajdonsággal rendelkeznek. Egyrészt glükózdependens módon, a hypoglykaemia veszélye nélkül (a szulfanilureához képest kifejezetten kedvezőbbek) csökkentik a vércukorszintet és ezért a $\mathrm{HbA}_{\mathrm{lc}}$-t is. A DPP4-gátlók a testtömeget nem növelik, ső́t azt kissé csökkenthetik is, ezzel szemben a szulfanilureák, a glitazonok és az inzulinok növelik azt. A DPP-4-gátlók előnyös tulajdonságai miatt szerepük jelentősen felértékelődött a 2-es típusú cukorbetegség kezdeti terápiájában [5].

A szitagliptin glykaemiás hatékonysága monoterápiában noninferior a szulfanilureákhoz (glipizid, glimepirid) $[14,15]$ és a metforminhoz képest [16]. Egy 24 hetes vizsgálatban Aschner és mtsai szignifikáns, 0,8\%-os $\mathrm{HbA}_{1 \mathrm{c}}$-csökkentést igazoltak a szitagliptint szedőkben [17].

Tekintettel arra, hogy a szitagliptin kombinálható többek között metforminnal, szulfanilureával, pioglitazonnal és inzulinnal, ezért a kombinációs terápia hatékonysága is fontos kérdés a mindennapos gyakorlat számára. Induló terápiaként metformint szedókben a hozzáadott szitagliptin a vizsgálat 30 . hetére további $1 \%$-os $\mathrm{HbA}_{1 c^{-}}$ csökkenést eredményezett [18], ugyanakkor kedvezően alakult az éhomi és az étkezés utáni vércukorszint is.

\section{A nonadherencia okai \\ 2-es tipusú cukorbetegekben}

A 2-es típusú cukorbetegség kezelése során számos tényező állhat a nem megfelelő terápiahưség hátterében, amelyek közül fontos szerepet játszhat a mellékhatásoktól, a hypoglykaemiától vagy a testtömeg-növekedéstôl való félelem. A nem megfelelő adherencia jelei közé tartozik a tartósan emelkedett $\mathrm{HbA}_{\mathrm{lc}}$-érték, a fokozott glykaemiás variabilitás, a beteg számára előírt vizitek kihagyása, a megtervezett laborvizsgálatok elmaradása, a vércukor-önellenőrzés elhagyása, az edukáció ellenére a testsúly folyamatos növekedése, az étrendi utasítások mellőzése, a diabeteses krízisállapotok ismétlődése, illetve az ismételt állapotromlás miatt gyakori külső segítség igénybevétele [19].

\section{Következtetések}

Retrospektív vizsgálatunkban az OEP receptkiváltási adatbázisát elemezve hasonlítottuk össze a metformin, illetve a szitagliptin/metformin fix kombináció egyéves terápiahúségét. Eredményeink igazolták, hogy a szitag- 
liptin/metformin fix kombináció terápiahüsége több mint kétszeresen jobb, mint a metforminé. Ennek jelentősége az, hogy a szitagliptin/metformin fix kombináció alkalmazásával egyrészt javul a betegek terápiahűsége, másrészt gyorsabban és hatékonyabban érhetők el a glykaemiás célok, ami hosszabb távon a micro- és a macrovascularis szövődmények kialakulásának késleltetésében játszik döntő szerepet.

\section{Limitációk}

Vizsgálatunkban retrospektív módon elemeztük az OEP adatbázisát. Módszerünkből adódóan nem tudtuk figyelembe venni a primer nonadherenciát (vizsgálatunk tárgya nem ez volt).

A perzisztenciaadatokat nem tudtuk a vizsgálatba belépés - első vénykiváltás - időpontja szerint megbontani: adatbázisunkban csak összesítve volt elérhető az utánkövetési idő. (Tehát ugyanúgy az egyéves perzisztenciába tartozott az, aki 2012. október 1-jétől 2013. szeptember 30-ig volt perzisztens és az, aki 2013. szeptember 30ától 2014. szeptember 29-ig.) Emiatt a vizsgálati periódus alatti esetleges, perzisztenciát befolyásoló tényezókben történt változásokat nem tudtuk vizsgálni.

Vizsgálatunk limitációja volt az is, hogy nem állt rendelkezésünkre adat a potenciális confounderekról, azaz azokról a változókról, amelyek egyszerre befolyásolhatják mind a gyógyszerrendelést, mind az adherenciát (például nem, életkor, szocioökonómiai státusz, betegségsúlyosság).

Anyagi támogatás: A szerzők anyagi támogatásban nem részesültek.

Szerzôi munkamegosztás: S. G.: A vizsgálat hipotézisének kidolgozása, adatgyűjtés megtervezése, kézirat megszövegezése. F. T.: A vizsgálat adatainak statisztikai feldolgozása, az ehhez kapcsolódó módszerek ismertetése, kézirat szövegezése. A cikk végleges változatát mindkét szerző elolvasta és jóváhagyta.

Érdekeltségek: A szerzőknek nincsenek érdekeltségeik.

\section{Irodalom}

[1] International Diabetes Federation: IDF Diabetes Atlas, 7th ed International Diabetes Federation, Brussels, Belgium, 2015.

[2] Jermendy, G., Nádas, J., Szigethy, E., et al.: Prevalence rate of diabetes mellitus and impaired fasting glycemia in Hungary - crosssectional study on nationally representative sample of people aged 20-69 years. Croat. Med. J., 2010, 51(2), 151-156.

[3] Lerman, I.: Adherence to treatment: the key for avoiding longterm complications of diabetes. Arch. Med. Res., 2005, 36(3), 300-306.
[4] Lawrence, D. B., Ragucci, K. R., Long, L. B., et al.: Relationship of oral antihyperglycemic (sulfonylurea or metformin) medication adherence and hemoglobin Alc goal attainment for HMO patients enrolled in a diabetes disease management program. J. Manag. Care Pharm., 2006, 12(6), 466-471.

[5] Inzucchi, S. E., Bergenstal, R. M., Buse, J. B., et al.: Management of hyperglycemia in type 2 diabetes, 2015: a patient-centered approach: update to a position statement of the American Diabetes Association and the European Association for the Study of Diabetes. Diabetes Care, 2015, 38(1), 140-149.

[6] Mills, M.: Introducing survival and event history analysis. Sage Publications, London, 2011

[7] Willett, J. B., Singer, J. D.: Investigating onset, cessation, relapse, and recovery: why you should, and how you can, use discretetime survival analysis to examine event occurrence. J. Consult. Clin. Psychol., 1993, 61(6), 952-965.

[8] Royston, P., Parmar, M. K.: Restricted mean survival time: an alternative to the hazard ratio for the design and analysis of randomized trials with a time-to-event outcome. BMC Med. Res. Methodol., 2013, 13, 152.

[9] Jermendy, Gy., Wittman, I., Nagy, L., et al.: Persistence of oral antidiabetic therapy in diabetic patiens between 2007 and 2009 in Hungary. (Az orális antidiabetikum-terápia perzisztenciája hazai cukorbetegek körében, 2007-2009 között). Metabolizmus, 2011, 9(1), 21-27. [Hungarian]

[10] Dunn, C. J., Peters, D. H.: Metformin. A review of its pharmacological properties and therapeutic use in non-insulin-dependent diabetes mellitus. Drugs, 1995, 49(5), 721-749.

[11] Strack, T.: Metformin: a review. Drugs Today (Barc.), 2008, $44(4), 303-314$.

[12] Mannucci, E., Ognibene, A., Cremasco, F., et al.: Effect of metformin on glucagon-like peptide 1 (GLP-1) and leptin levels in obese nondiabetic subjects. Diabetes Care, 2001, 24(3), 489494.

[13] Scheen, A. J.: A review of gliptins in 2011. Expert Opin. Pharmacother., 2012, 13(1), 81-99.

[14] Seck, T., Nauck, M., Sheng, D., et al.: Safety and efficacy of treatment with sitagliptin or glipizide in patients with type 2 diabetes inadequately controlled on metformin: a 2 -year study. Int. J. Clin. Pract., 2010, 64(5), 562-576.

[15] Arechavaleta, R., Seck, T., Chen, $\Upsilon$., et al.: Efficacy and safety of treatment with sitagliptin or glimepiride in patients with type 2 diabetes inadequately controlled on metformin monotherapy: a randomized, double-blind, non-inferiority trial. Diabetes Obes. Metab., 2011, 13(2), 160-168.

[16] Aschner, P., Katzeff, H. L., Guo, H., et al.: Efficacy and safety of monotherapy of sitagliptin compared with metformin in patients with type 2 diabetes. Diabetes Obes. Metab., 2010, 12(3), 252261.

[17] Aschner, P., Kipnes, M. S., Lunceford, J. K., et al.: Effect of the dipeptidyl peptidase- 4 inhibitor sitagliptin as monotherapy on glycemic control in patients with type 2 diabetes. Diabetes Care, 2006, 29(12), 2632-2637.

[18] Raz, I., Chen, $\Upsilon$., Wu, M., et al.: Efficacy and safety of sitagliptin added to ongoing metformin therapy in patients with type 2 diabetes. Curr. Med. Res. Opin., 2008, 24(2), 537-550.

[19] Leichter, S. B.: Making outpatient care of diabetes more efficient: analyzing noncompliance. Clin. Diabetes, 2005, 23(4), 187190.

(Simonyi Gábor dr., Budapest, Tétényi út 12-16., 1115 e-mail: bmbel3@gmail.com)

Az összefoglalóban szereplő információk a szerző(k) nézeteit tükrözik.

Bármely említett termék alkalmazásakor az érvényes alkalmazási előírás az irányadó. 